\title{
NIEZNANE KSIAZZKKI ZE ZBIORÓW ANDRZEJA FRYCZA MODRZEWSKIEGO
}

Na temat Andrzeja Frycza, jego życia, działalności publicznej i literackiej istnieje dość zasobne piśmiennictwo. Omówił je szeroko Jerzy Starniawski w jednym z rozdziałów książki - „Andrzej Frycz Modrzewski. Życie, dzieło, sława” (Łódź 1981) ${ }^{1}$. Kończy ów rozdział uwagą o potrzebie napisania monografii o stylu pisarskim Frycza.

Jak sądzę, w celu jej napisania, przydatna będzie znajomość biblioteki domowej uczonego, a nie tylko lektur, które czytał. Kanon tych ostatnich można odtworzyć z książek cytowanych w jego autorskich publikacjach ${ }^{2}$. Książki z jego księgozbioru prywatnego zajmują szczególne miejsce w grupie lektur. Do nich przecież zaglądał najczęściej. Ich analiza, między innymi pod kątem uwag czytelniczych samego Frycza, może poszerzyć naszą wiedzę o zakresie jego warszatu pisarskiego ${ }^{3}$.

Badacze dotychczas bardziej interesowali się losami ksiażek autorstwa Frycza niż jego księgozbiorem ${ }^{4}$. Tymczasem przy poszukiwaniu książek z księgozbioru Stanisława Karnkowskiego, niegdyś biskupa diecezji, w której zamieszkiwał Frycz i arcybiskupa w Gnieźnie, zebrałem informacje o pięciu woluminach oznaczonych autografami Andrzeja Frycza. Do tych dołączam jeszcze jedną książkę nie oznakowaną proweniencją Frycza, ale niegdyś będącą, jak sądzę, w zbiorze podręcznym Modrzewskiego. Jest to podręcznik wymowy Kwintyliana pt. „Wykształcenie mówcy" . Książka ta była własnością Jana Łaskiego II (młodszego), co potwierdza ręczna zapiska na karcie tytułowej: „Joannis a Lasco Poloni et amicor[um]”. Znając stosunek Karnkowskiego i Modrzewskiego do Łaskiego, wydaje się, iż jedyna droga jej do biblioteki Karnkowskiego wiodła poprzez dom wolborski Frycza.

Tak więc można mówić o sześciu woluminach dawnej biblioteki prywatnej Andrzeja Frycza Modrzewskiego.

Książki do Wolborza zwiózł Frycz, kiedy przeniósł się tam na stałe po roku $1552^{7}$. Badacze opisujący okoliczności tej przeprowadzki podnoszą, iż był „pozbawiony szerszego dostępu do umiłowanych książek"8. Formułując taki pogląd zapominają o roli biblioteki biskupów włocławskich w ich rezydencji wolborskiej i prywatnego księgozbioru Frycza. Dalsze poszukiwania tego księgozbioru pozwolą nam ocenić jego aktualność i wartość merytoryczną dla pisarstwa Frycza. Artykuł niniejszy jest małym wkładem w rozwiazanie tej zagadki.

Książki Frycza w posiadanie Stanisława Karnkowskiego dostały się najprawdopodobniej po opuszczeniu przez Modrzewskiego Wolborza w roku $1568^{9}$. Być może, iż w znaną kwotę 1000 złotych polskich, zdaniem badaczy danych za wójtostwo w Wolborzu, wliczono opłatę także za księgozbiór, bądź niektóre egzem- 
plarze książek stanowiących dokumentację w pracy pisarskiej niepokornego autora. Na taką interpretację pozwalałby zwrot $\mathrm{z}$ dokumentu o ustąpieniu $\mathrm{z}$,bonis omnibus" "10. Książki mogły być interesujące dla czynników kościelnych z powodu uwag marginalnych Frycza i dla S. Karnkowskiego ze względów bibliofilskich. W innym przypadku znalazłyby się w rezydencji biskupa kujawskiego w Wolborzu, po śmierci autora „O poprawie Rzeczypospolitej” (1572 r.).

Po wyborze S. Karnkowskiego na prymasaw r. 1581 jego prywatny księgozbiór przewieziono w Wolborza do Łowicza na zamek arcybiskupów gnieźnieńskich. Tam część książek z autografami Frycza, łącznie z dawną książką Łaskiego, otrzymały później odcisk pieczęci własnościowej (bibliotecznej) arcybiskupa gnieźnieńskiego. Inny był los dwóch woluminów teologicznych ${ }^{11}$. Karnkowski darował je jednemu ze swoich archidiakonów w r. 1577. Było to w pięć lat po śmierci Andrzeja Frycza. I w tym wypadku dokładniejsze okoliczności zmiany właściciela są nie znane. Tym nowym właścicielem, przejściowym, był Wojciech Gadomski, świeżo mianowany archidiakonem pomorskim $\left(1576\right.$ r.) ${ }^{12}$. Fakt darowizny Gadomski odnotowal na karcie tytułowej obu woluminów „Summae theologicae" św. Tomasza z Akwinu, pisząc: „Per R[everendissi]um D[ominum] Stanislaum Carncowski (!) D[ei] G[ratia] Ep[iscop]um Wlad[islaviensem] et Pomeraniae mihi Alb[erto] Gadomski Arch[idiacono] Pomeraniae dono datus Wolborii A[nno] D[omini] 1577" (BUW sygn. Sd 602 244). Dokładność opisu aktu darowizny nie dziwi skoro pamięta się, iż pisał to prawnik, a do tego były kanclerz biskupa poznańskiego. Ale może zastanawiać wybór książki darowanej nowo mianowanemu dostojnikowi. Czyżby Karnkowski czynił to wyłącznie z powodu trudnego terenu pracy archidiakona? Pozostale dzieła, jak wspomniałem, zabrał prymas ze sobą do Łowicza, gdzie ostemplowano je pieczątką arcybiskupa ${ }^{13}$. Taką pieczątkę miał niewątpliwie także tom „Digestów" Justyniana Wielkiego ${ }^{14}$. Hipotezę taką stawiam w wyniku następującego spostrzeżenia: karta tytułowa w środku dolnego brzegu książki ma wyrwany fragment papieru. Ślad wskazywałby, iż uszkodzenie powstało w związku z pieczątką biblioteczną arcybiskupa. Taki wyrwany fragment, po wyrównianiu strzępiastych brzegów, miałby rozmiary prostokąta reprodukowanej kartki ekslibrisowej Karnkowskiego $(55 \times 40 \mathrm{~mm})^{15}$. Nie znajdując w odnalezionym zbiorze książek S. Karnkowskiego przykładu takiej kartki ekslibrisowej, utwierdzam się w przekonaniu, że cytowane w literaturze ekslibrisy prymasa mają taką genezę!

Późniejszych właścicieli książek Frycza odnotowuję w dołączonym aneksie, zawierającym odnalezione książki ze zbiorów Modrzewskiego.

Obecnie z omawianych sześciu woluminów cztery przechowuje Biblioteka Uniwersytecka w Warszawie ${ }^{16}$, a dwa biblioteka kapituły w Łowiczu ${ }^{17}$.

Na Frycza jako pierwszego właściciela omawianych książek wskazują autograficzne znaki własnościowe ${ }^{18}$. Ze sposobu rozmieszczenia na książkach można wydzielić z nich dwie grupy. Pierwszą tworzą tradycyjne napisy ręczne na karcie tyłułowej, drugą napisy również ręczne, ale na górnym brzegu książki i to składające się z tytułu oraz znaku własności. Do pierwszej grupy należą trzy woluminy drukowane w latach 1547-1549. Dwa z nich stanowią jedno dzieło teologiczne, a trzeci introligatorski klocek prawniczy. Dziełem teologicznym była wspomniana poprzednio pełna „Summa theologica" św. Tomasza z Akwinu z komentarzem 
kardynala Tomasza de Vio zwanego Kajetanem ${ }^{19}$. Kardynał ten przeszedł do historii głównie w związku z Marcinem Lutrem. Prowadził przeciw niemu początkowe postępowanie dyscyplinarno-sądowe. Ważność postaci komentatora uwidacznia złocony tytuł na okładzinie pierwszego woluminu: „CAIETANUS SUPER PRIMAM // ET PRIMAM S[E]C[UN]DAE // 1551 // S[ANCTI] THOMAE". Cyfry arabskie - 1551 - odnotowują datę oprawy książki drukowanej w r. 1547 w Lyonie. Włączenie jej do księgozbioru Frycza w tym czasie uwiarygodnia tezę badaczy: program literacki Modrzewskiego około r. 1555 został ukierunkowany na tematy ściśle teologiczne $e^{20}$. Egzemplarz ten czyni też zrozumiałym częste powoływanie się Frycza na autorytet św. Tomasza z Akwinu i przytaczanie jego poglądów ${ }^{21}$; ma liczne marginalia, zwłaszcza w drugiej części dzieła (Prima secundae pars) ${ }^{22}$.

Równie interesujący, choć z innych powodów, jest klocek introligatorski zawierający dwa dzieła współczesnych prawników ${ }^{23}$. Na początku - dzieło Franciszka Hotmana (zm. 1594 r.), francuskiego prawnika, który wywarł znaczny wpływ na prawodawstwo niemieckie. Hotman był znany z tego, iz - zdaniem Janusza Pelca - najobszerniej ujął teorię frankogallizmu w zakresie genealogii narodowej. Dla poparcia swoich teorii republikańskich odwoływał się do przykładu Polski ${ }^{24}$. Był związany z kalwinizmem i protestantyzmem ${ }^{25}$.

Drugie dzieło, wielokrotnie wydawane, wywodziło się także z kręgów protestanckich. Był to "Lexicon iuris" Hermana Figulusa (właśc. nazwisko Ulner) ${ }^{26}$. Dzieło to było wyciagiem z pism i wykładów Jana Oldendorpa (zm. 1567 r.) ${ }^{27}$. Oldendorp był w Polsce znanym jurystą, jak można sądzić z ilości jego tytułów w bibliotece Zygmunta Augusta ${ }^{28}$.

Czas nabycia książek tej grupy wiąże się z latami druku dzieła „O poprawie Rzeczypospolitej", najpierw okrojonej wersji, potem pełnej, uzupelnionej dalszymi traktatami w części o Kościele.

Po tych uwagach ważnych, a dotyczących strony formalnej i treściowej książek, wróćmy do sprawy proweniencji. Na karcie tytułowej cytowanego dzieła św. Tomasza z Akwinu Frycz napisał w pustym medalionie drukarskim „Sum Fricij”. Uczynił to $w$ każdym z dwóch woluminów. W klocku introligatorskim z dziełami prawniczymi ograniczył się do sygnowania pierwszego utworu, pisząc na górze karty tytułowej „Fricij”.

Inne miejsca do oznaczenia proweniencji wybrał w dwóch pozostałych woluminach prawniczych. Umieścił ją na górnym brzegu książki razem ze skrótem tytułu, co miało ułatwiać korzystanie z ksiażek. Były to ksiazzki wydane w latach 1509 i 1529. Nabył je Frycz prawdopodobnie w czasie pobytu za granicą w latach 1536-1540. Można tak mniemać na podstawie ornamentu oprawy ${ }^{29} i$ ewentualnie daty radetka $(1539)^{30}$. Miasta druku tych książek - Lyon, Norymberga - były wówczas miejscami pobytu Frycza ${ }^{31}$. Zakupione tam książki należaly do podstawowych tytułów do nauki prawa rzymskiego. Były to dwie części "Digestów" Justyniana Wielkiego, występujące $w$ literaturze równolegle pod greckim tytulem „Pandektai”. Z całości liczącej trzy części, w zbiorze Frycza ocalała część początkowa, zwana w średniowieczu Digestum vetus, i środkowa, najpoźniej odkryta, zwana Infortiatum. Egzemplarz Fryczowy tej ostatniej występuje z tekstem komentowanym w układzie tzw. modus modernus. W Digesta vetus Frycz wykonał napis 
„PAnd[ectae lub - ektai] p[ar]s // Fricij”, a w części środkowej „Infort[iatum] // Fricij” Nadto w tej części „Digestów” nakreślił dwa razy skróty tytułów, raz na żłobku w formie użytkowego zdobienia "INFORTIA[TUM]", drugi raz na górnej okładzinie oprawy w formie kaligraficznego „INFOR[TIATUM]”. W części natomiast zwanej vetus był wytłoczony na okładzinie górnej złocony tytuł „PARS PRIMA LIBRO // RUM DIGES // TORUM".

Książki z tak oznakowaną proweniencją były czytane. Część pierwsza „Digestów" (w ks. III, w tytule 2. De his qui notatur infamia) ma uzupetnienie uczonego na marginesie - „secus si alieno in Christo”, odnoszące się do tekstu "suo [uzupełnienie] nomine damnatus" (s. 97). W tym samym tytule, tylko dwie strony dalej, występuje podkreślenie słów - „si quis alieno nomine condamnatus”. Czytając te noty czytelnicze Frycza, łączy się je mimowoli z głośną dysputą wolborską Frycza ze Stanisławem Orzechowskim z roku 1561.

Prezentowana tutaj literatura prawnicza znajduje swoje odbicie na łamach twórczości $\mathrm{Frycza}^{32}$, jednego z nielicznych pisarzy tego czasu poświęcających osobną księgę rozważaniom nad prawem w traktacie „O poprawie Rzeczypospolitej” ${ }^{33}$. Wcześniej korzystał z tej literatury przy debiucie pisarskim o nazwie „Łaski czyli o karze za mężobójstwo" (1545 r.).

Przedstawione ksiażki Frycza stanowią jakiś fragment jego księgozbioru. Poszukiwania dalszych egzemplarzy wymagają systematycznych badań proweniencyjnych na drukach obcych XVI w. W bibliotekach polskich prowadzi się przede wszystkim poszukiwania w dziale poloników. Doprowadziło to do znalezienia autografów donacyjnych Andrzeja Frycza Modrzewskiego na jego egzemplarzach autorskich $^{34}$. Wobec tego, odkrycie dalszych książek z proweniencją Frycza pozostaje sprawą przypadku bądź przyszłych intensywniejszych badań proweniencyjnych.

\section{Przypisy}

${ }^{1}$ S. 123-167; zob. Andrzej Frycz Modrzewski. Bibliografia zestawiona przez Pracownię Bibliografii Staropolskiej Instytutu Badań Literackich, Wrocław 1962.

${ }^{2}$ Zob. T. Bieńkowski, Warsztat pisarski Frycza Modrzewskiego, [W:] Andrzej Frycz Modrzewski i problemy kultury polskiego Odrodzenia. Pod red. T. Bieŕkowskiego, Wroclaw 1974, s, 125-126. Studia Staropolskie, t. 42.

${ }^{3}$ Zob. tamże uwagi T. Bieńkowskiego na s.: 122, 124 i 125.

${ }^{4}$ Zob. S. Kot, Andrzej Frycz Modrzewski. Studium z dziejów kultury polskiej XVI w., Kraków 1923, s. 289-302.

${ }^{5}$ Zob. Areks: Quintilianus.

${ }^{6}$ Biblioteka Uniwersytecka w Warszawie (dalej cyt. BUW) sygn. 28.14.4.16.

${ }^{7}$ M. Korolko, Andrzej Frycz Modrzewski. Humanista, pisarz, Warszawa 1978, s. 60.

${ }^{8}$ Tamże, s. 60; por. W. Voisé, Oryginalność i wtómość myśli Frycza Modrzewskiego, [W:] Andrzej Frycz Modrzewski..., s. 36.

${ }^{9}$ O okolicznościach eksmisji A. Frycza Modrzewskiego piszą m.in. S. Kot, op.cit., s. 262-265; J. Starnawski, op.cit., s. 34.

${ }^{10}$ Zob. W. Urban, Do biografii Frycza Modrzewskiego, [W:] Andrzej Frycz Modrzewski..., s. 228. 
${ }^{11}$ BUW sygn.: Sd. 602.244 ${ }^{1-11} 1$; Sd.602.244 $4^{11} 2^{-111}$.

${ }^{12}$ A. Boniecki, Herbarz polski, Cz. 1, t. 5, Warszawa 1902, s. 337; por. K. Niesiecki, Herbarz polski, t. 4, (repr. Warszawa 1978), s. 39.

${ }^{13}$ BUW sygn.: Sd. 608.1722-1723; 28.13.4.16; Biblioteka Kapituly Łowickiej w Łowiczu (dalej cyt. BKL) sygn.: $482 ; 731$.

${ }^{14}$ BKt sygn. 482.

${ }^{15}$ E. Chwalewik, Ekslibrisy polskie szesnastego i siedemnastego wieku, Wrocław 1955, s. 35 przyp. 99; zob. W. Wittyg, Exlibrisy bibliotek polskich XVII i XVIII w., Warszawa 1903, s. 13; K. Walczak, Z dziejów najstarszych bibliotek szkolnych Kalisza, "Roczn. Biblioteczne” 1981, z. 1-2, s. 6.

${ }^{16}$ BUW sygn.: Sd. 602.244 ${ }^{|-1|} 1 ;$ Sd. 602.244 $2^{\| \prime \prime I}$; Sd. 608.1722-1723; 28.13.4.16.

17 BKŁ sygn.: 482; 731.

${ }^{18}$ Z czasów poznańskich Frycza zachowaly się jego pierwsze autografy; zob. 1. Warmiński, Kilka nowych kart zżycia Andrzeja Frycza zwanego Modrzewskim, Poznań 1908 (odb. Rocz. Tow. Przyjaciół Nauk, s. 6-13); J. Starnawski, op. cit., s. 16.

${ }^{19}$ Zob. przyp. 11.

${ }^{20}$ Np. M. Korolko, op.cit., s. 60.

${ }^{21}$ W. Voisé, Andrzej Frycz Modrzewski 1503-1572, Wroclaw 1975, s. 123; tenże, Oryginalność i wtórność myśli..., s. 33.

22 Należy żałować, iż w momencie pisania artykułu "Summa theologica" nie byla dostępna z powodu remontu Działu Starych Druków BUW.

${ }^{23}$ BUW sygn. Sd. 608.1722-1723.

${ }^{24} \mathrm{~J}$. Pelc, Literatura polskiego Odrodzenia a prądy umyslowe epoki, [W:] Andrzej Frycz Modrzewski..., s. 23.

${ }^{25}$ Neue Deutsche Biographie, t. 9, Berlin 1972, s. 653.

${ }^{26}$ C.G. Jöcher, Allgemeines Gelehrten-Lexicon..., t. 4, Leipzig 1750, szp. 1672.

27 Tamże, t. 3, szp. 1046.

${ }^{28}$ A. Kawecka-Gryczowa, Biblioteka ostatniego Jagiellona. Pomnik kultury renesansowej, Wroctaw 1988 , s. 159.

${ }^{29}$ BKŁ sygn. 731.

${ }^{30}$ BKŁ sygn. 482.

${ }^{31}$ W r. $1536 / 7$ odbywał na wasny koszt podróż z Bazylei do Paryża przez Lyon: W. Urban, biogram A. Frycza Modrzewskiego [w:] Polski slownik biograficzny, t. 21, Wrockaw 1976, s. 539.

${ }^{32}$ A. Klinger, Myśl filozoficzno-spoteczna Andrzeja Frycza Modrzewskiego, Zielona Góra 1978, s. 73.

${ }^{33}$ Zob. Historia nauki polskiej, t. 1, Wroclaw 1970, s. 389.

${ }^{34}$ Zob. np. M. Bohonos, Katalog starych druków Biblioteki Zakł. Nar, im. Ossolińskich, Polonica XVI w., Wroctaw 1965, nr: 1596c, $1607^{\mathrm{b}}$. 
Aneks

\section{OPIS ODNALEZIONYCH KSIAZZEK ANDRZEJA FRYCZA MODRZEWSKIEGO}

Przy cytatach bibliograficznych zastosowano skróty:

Adams H.M. Adams: Catalogue of books printed on the continent of Europe, 1501-1600 in Cambridge Libraries. Vol. 1-2. Cambridge 1967.

Baudrier [H.L.] Baudrier: Bibliographie lyonnaise. Recherches sur les imprimeurs, libraires, relieurs et fondeurs de lettres de Lyon au $X V I^{e}$ siècle... Publiées et continuées par J. Baudrier. T. 1-12; Tables par G. Tricou. Paris repr. 1964. Tables 1965.

CBN Catalogue général des livres imprimés de la Bibliothèque Nationale. T. 1-. Paris 1924.

VD 16

Verzeichnis der im deutschen Sprachbereich erschienenen Drucke des XVI. Jahrhunderts. Herausgegeben von der Bayerischen Staatsbibliothek in München in Verbindung mit der Herzog August Bibliothek in Wolfenbüttel. T. 1-. Stuttgart 1983-.

FIGULUS HERMANUS (Ulner Hermann ca 1565)

1. Lexicon iuris seu Epitome definitionum et rerum ... : ex omnibus quae Joannes Oldendorpius partim edidit ... partim docuit / concinnata per Hermannum Figulum ... - Lugduni : apud Gulielmum Rouillium, 1549 , -360 s. ; $8^{\circ}$.

CBN 126, 880.

Prow. i opr. zob. poz. 2

BUW sygn. Sd. 608.1723 adl.

HOTOMANUS FRANCISCUS (Hotman François 1524-1594)

2. In tractatum de actionibus ex libro Institutionum iuris quarto . / Franciscus Hotomanus . - Lugduni : apud Seb[astianum] Gryphium, 1548. - 283 s. ; $8^{\circ}$.

CBN 73, 1048.

S. 209-210, 223-224 mylnie powtómie opraw. po indeksie.

Prow.: 1. A. Frycz Modrzewski. 2. S. Karnkowski [piecz.]. 3. „Stanislai Wisoczki de Dambie C[anonici ?] Lanciciensis] Secretarii Regii” [XVI/XVII]. 4. "Eccl[esi]ae Konic[ensis]" [XVII]. 5. „Ex libris Gaspari Sulcz Conc[ionatoris] Baran[oviensis]" [zamazanie]; „Ex libris R[evere]ndi Gaspari Sulcz Praep[osi]ti in Kurow et Klimentowicze" [XVII].

Opr. XIX w.

BUW sygn. Sd. 608.1722 adl. 


\section{[JUSTINIANUS I 527-565]}

3. Digestorum seu pandectarum libri quinquaginta ... / editi... per Gregorium Holoandrum... - Norembergae : excudebat Joannes Petreius, 1 IV 1529. -3 vol; $4^{\circ}$.

P. 1: [23] [1 cz.] k., $720 \mathrm{~s}$.

VD 16 C-5246.

Data w kolof.: Cal. Apr. M. D. XXIX.

Prow.: 1. A. Frycz Modrzewski. 2. S. Karnkowski (?). 3. „Ecclesiae Collegiatae Lovicensis" [XVIII].

Opr.: deska, brun. sk., tłocz. na śl., złoc.; tytuł.

BKŁ sygn. 482

\section{[JUSTINIANUS I 527-565]}

4. Infortiatum sacratissimar[um] legu[m] noviter... impressum... / emendatum per... Johannen de gradibus... ; [cum casi[bus] Bartoli Nicolai de Neapoli, Alex[andri] de imola et aliorum doctoru[m]]...-In... Lugdun[i] : per Nicolaum de B[e]n[e]dictis, 23 VII 1509. - CCLXXXII, 6 k. ; $2^{\circ}$.

Adams J-537.

Koment. wymienieni w kolof. - Data w kolof.: M.ccccc.nono. die XXiij.Jullij.

Prow.: 1. A. Frycz Modrzewski. 2. S. Karnkowski [piecz.]. 3. „Ecclesiae Collegiatae Lovicensis" [XVIII].

Opr.: deska, braz. sk., trzy rodzaje radelek (motywy roślinno-zoologiczne), pozostałości po zapięciu; tytuł atram.

BKŁ sygn. 731

\section{QUINTILIANUS MARCUS FABIUS (ca 35 - ca 95)}

5. M[arcus] F[abius] Quintilianus : [De institutione oratoria liber primus - duodecimus]. - Venetiis : in aedibus Aldi et Andreae Soceri, VIII 1514. - [4, ost. cz.], 230 k.; $4^{\circ}$. Adams Q-52.

Data w kolof.: Mense Augusto M.D. XIIII.

Prow.: 1. Jan Łaski młodszy. 2. S. Karnkowski [piecz.]. 3. „Inscriptus C[atalo]go Soc[ietatis] JESU Caliss[iae]" [XVI]. 4. „Z bibl[ioteki] Szkoły Woiewodzk[iej] Kalisk[iej]"; to samo na s. 49-50 [XVIII].

Marginalia i podkreślenia; uzupełnienie indeksu.

Opr.: tektura, brąz. sk., zdob. radetkiem żołędzia ulistn; opr. górna luzem.

BUW sygn. 28.13.4.16

THOMAS DE AQUINO s. (1226-1274)

6. Prima [-tertia] pars operum... Thomae Aquinatis... Summae Theologiae... / Thomae à Vio... cardinalis Caietani Commentariis illustrata... : huic... addidae sunt theologorum annotationes et postillae... - Lugduni : apud Hugonem et 
haeredes Aemonis a Porta ; excud. Franc[iscus] et Claud[ius] Marchant fratres, II 1547-1548. -2 vol. : $2^{\circ}$.

[T. 1] : Prima... - [20], 263, [1 cz.] k.

[T. 2] : Prima secundae... - VII 1547. - [24], 173, [1 cz.] k.

[T. 3] : Secunda secundae... - 1547 (1548). - [22], $324 \mathrm{k}$.

[T. 4] : Tertia... - [18], $191 \mathrm{k}$.

Wydanie nie odnotowane nawet u Baudriera; Centralny Katalog Biblioteki Narodowej w Warszawie: Bibl. Główna UMK w Toruniu Ob. 6.III.1029.

T. 1-2, 3-4 współopr.

Prow.: [T. 1]. 1. A. Frycz Modrzewski. 2. S. Karnkowski. 3. Wojciech Gadomski (1577). 4. „N[icolaus] B[onkowski] P[raepositus] C[ervenscensis]” [XVI].

[T. 2]. 1. „Per R[evere]ndum Praep[osi]tum Valentinum Klyceniu[m] Praep[osi]tum Pomnichovien[sem] mihi Nicoalo Bonkowskij Conventus Ceruensc[ensis] Priori dono datus Anno D[omi]ni 1591". 2. "NB" (= Mikołaj Bonkowski).

[T. 3]. 1. A. Frycz Modrzewski. 2. „Per R[everendissi]mum D[ominum] Stanislaum Carncowski (!) D[ei] G[ratia] Ep[iscop]um Wlad[islaviensem] et Pomeraniae mihi Alb[erto] Gadomski Arch[idiacono] Pomeraniae dono datus A[nno] D[omini] 1577”. 3. „Sum Nicol[ai] Bonk[owski]”.

[T. 4]. 1. „Per R[evere]ndum P[at]rem Klicenium Praep[osi]tum Pomnichovien[sem] mihi Nicolao Bonkowskij Conventus Cerven[scensis], Priori dono in pignus fr[ater]ni amoris datus A[nno] D[omini] 1591". 2. „N[icolaus] B[onkowski] P[rior] C[ervenscensis]"

Marginalia zapisane ręką Frycza (?).

Na wklejce przedniej v. (t. 3) ręką Bonkowskiego dłuższy zapis o śmierci Andrzeja Batorego $z$ datą $31 \times 1599$.

Opr.: 1551; Deska, jasna sk. i brun., tt. na ślepo, radełka medalionowo-roślinne z datą 1540, śl. wiązań; tytuł (wol. 1).

BUW sygn. Sd. $602.244^{i-I I I}$ 